\title{
THE ROLE OF DIETARY POLYUNSATURATED FATTY ACIDS IN INFLAMMATION
}

\author{
Vesna Vucic \\ Centre of Research Excellence in Nutrition and Metabolism, Institute for Medical Research, \\ University of Belgrade, Serbia
}

\section{ULOGA POLINEZASIĆENIH MASNIH KISELINA U INFLAMACIJI}

\author{
Vesna Vučić \\ Centar izuzetne vrednosti u oblasti istraživanja ishrane i metabolizma, Institut za medicinska istraživanja, \\ Univerzitet u Beogradu, Srbija
}

\section{ABSTRACT}

Low-grade systemic inflammation is at the base of the most chronic non-communicable diseases, which are reaching epidemic proportions worldwide. Key players in the regulation of inflammation are $n-6$ and $n-3$ polyunsaturated fatty acids (PUFAs), in particular arachidonic acid (n-6) and eicosapentaenoic acid (n-3). They are precursors of eicosanoids - signaling molecules involved in modulating the intensity and duration of inflammatory responses. Eicosanoids derived from n-6 PUFAs have proinflammatory actions, while those derived from n-3 PUFAs act anti-inflammatory. Therefore, dietary intake of n-6 and n-3 PUFAs, as well as their ratio, could markedly affect the pathogenesis and manifestation of many chronic diseases associated with low-grade inflammation. This review will focus on the relationship between dietary PUFAs and inflammation, with reference to PUFAs status in plasma phospholipids in Serbian population.

Keywords: Polyunsaturated fatty acids, inflammation, arachidonic acid, eicosapentaenoic acid, eicosanoids, cytokines
\end{abstract}

\section{SAŽETAK}

U osnovi većine hroničnih nezaraznih bolesti, koje širom sveta dostižu epidemijske razmere, leži "tiha“ inflamacija. Ključni igrač u regulaciji inflamacije su polinezasićene masne kiseline (PNMK) n-6 i n-3 familije, posebno arahidonska (n-6) i eikozapentaenska kiselina (n-3). One su prekursori eikozanoida - signalnih molekula koji su uključeni u intenzitet $i$ trajanje inflamatornog odgovora. Eikozanoidi poreklom od n-6 PNMK deluju proinflamatorno, dok oni poreklom od n-3 PNMK imaju anti-inflamatorno dejstvo. Zbog toga dijetarni unos n-6 i n-3 PNMK, kao i njihov odnos, može značajno da utiče na patogenezu $i$ manifestaciju mnogih hroničnih oboljenja koja su povezana sa "tihom" inflamacijom. Ovaj pregledni rad se bavi vezom između unosa PNMK $i$ inflamacije, sa osvrtom na status n-3 i n-6 masnih kiselina u fosfolipidima plazme u populaciji u Srbiji.

Ključne reči: Polinezasićene masne kiseline, inflamaci$j a$, arahidonska kiselina, eiokozapentaenska kiselina, eikozanoidi, citokini

\section{ABBREVIATIONS}

AA - arachidonic acid ALA - alpha-linolenic acid CRP - C-reactive protein DGLA - dihomo- $\gamma$-linolenic acid DHA - docosahexaenoic acid DPA - docosapentaenoic acid DTA - docosatetraenoic acid EPA - eicosapentaenoic acid IL - interleukine
LA - linoleic acid LT - leukotrienes NFкB - nuclear factor $\kappa$ B PG - prostaglandins PPAR - peroxisome proliferation activator receptor PUFAs - polyunsaturated fatty acids TX - thromboxanes TNF- $\alpha$ - tumor necrosis factor- $\alpha$ WHO - World Health Organisation
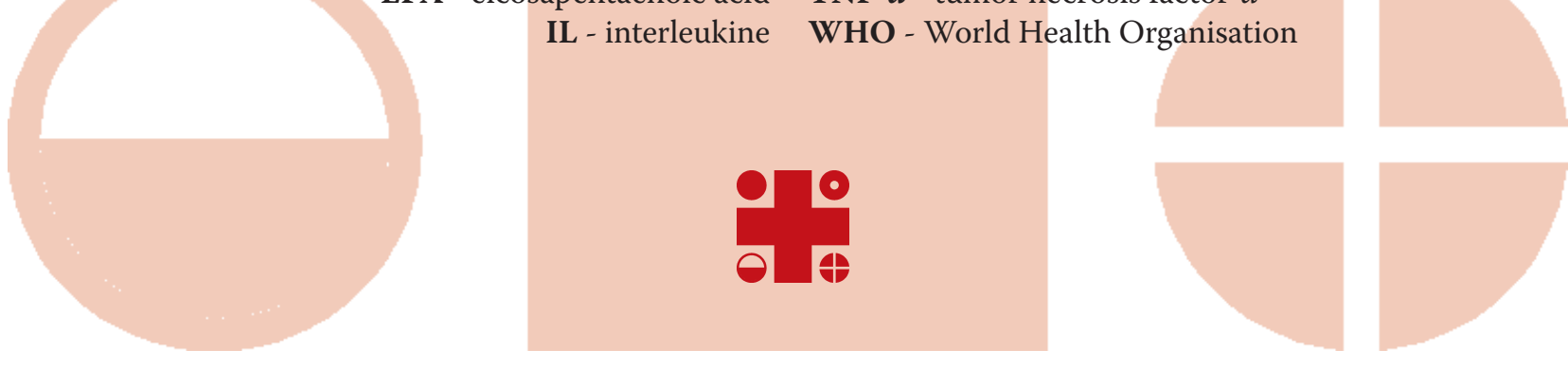

UDK: 616-002:577.115.3 / Ser J Exp Clin Res 2013; 14 (3): 93-99 DOI: 10.5937/SJECR14-4774 
Chronic non-communicable diseases, which include cardiovascular disease, type 2 diabetes, cancer and chronic respiratory conditions, are steadily increasing and the major cause of death worldwide. A key player in the pathogenesis of most non-communicable diseases is low-grade inflammation, characterized by increased systemic levels of some cytokines and C-reactive protein (CRP). Low-grade systemic inflammation has been associated with obesity, atherosclerosis and type 2 diabetes (1). Several factors may cause chronic inflammation, but the most important ones are unhealthy diet and sedentary lifestyle (2). According to the World Health Organization (WHO) the major nutritive risk factors for chronic diseases are high energy intake, high intake of total fats, saturated and trans fatty acids, cholesterol, refined carbohydrates and alcohol, with low intake of dietary fibers, antioxidants and n-3 polyunsaturated fatty acids (PUFAs) (3).

PUFAs are vitally important constituents of cell membranes which maintain membrane fluidity, assure the optimal environment for function of membrane proteins and regulate many cellular functions (4). There are two principal series of PUFAs: the $n-3$ and the n-6 families. They are physiologically and metabolically distinct and have different effects on human health. Precursors for synthesis of long-chain PUFAs are the 18-carbon fatty acids: linoleic acid (18:2n-6, LA) and alpha-linolenic acid (18:3n-3, ALA). They are essential fatty acids, which cannot be synthesized by mammals and therefore have to be obtained from the diet (5). Once ingested, LA can be converted to other n-6 PUFAs, and ALA to n-3 PUFAs by the relevant desaturase and elongase enzymes. As a consequence, the relative dietary amounts of LA and ALA determine the relative cellular content of n-3 and n-6 PUFAs. Although the ratio of $n-6 / n-3$ PUFAs in the diet should not exceed 4 , this ratio is typically $15-20$ in the Western diet (6). This predominance of $n-6$ fat is due to the abundance in the diet of LA, which is present in high concentrations in soy, corn, safflower, and sunflower oils and in products made from these oils. By contrast, there is a low intake of n-3 PUFAs: ALA, which is present in leafy green vegetables, some nuts and in linseed and canola oils, as well as eicosapentaenoic (20:5n-3, EPA) and docosahexaenoic acid (22:6n-6, DHA) which are found in cold water fish (5). Since the most often consumed oil in Serbia is sunflower oil, with low intake of sea food and linseed oil (7), it can be assumed that the n-6$/ \mathrm{n}-3$ ratio in the diet is very high.

\section{LIPID AND PEPTIDE INFLAMMATORY MEDIATORS}

The clinical signs of inflammation, such as pain, redness and swelling, result from the release of lipid (eicosanoids) and peptide (cytokines) inflammatory mediators. In response to trauma or an acute infection by pathogens, the level of cytokines in the circulation will increase. The first cytokines as they appear are tumor necrosis factor- $\alpha$ (TNF- $\alpha$ ), interleukines IL-1 $\beta$, IL-6, IL-1 receptor antagonist (IL-1ra), soluble TNF- $\alpha$-receptors (sTNF-R), and IL-10 (2). Concentration of acute phase proteins from liver, such as CRP, rises as well. The elevation of cytokines in chronic low-grade inflammation is markedly lower than in an acute response: it is usually 2-3 fold higher than physiological levels (8). Nevertheless, recent studies have shown that plasma levels of IL-6, TNF- $\alpha$, and in particular CRP, can predict the risk of myocardial infarction (9-11). The stimuli for the production of cytokines in chronic low-grade inflammation are still unknown, but the role of nutritional factor could not be excluded. Furthermore, the adipose tissue has been assumed as an origin of TNF- $\alpha$ in low-grade systemic inflammation (12). High levels of circulating TNF- $\alpha$ were found in people with type 2 diabetes, and its direct role in insulin resistance and metabolic syndrome was documented in several studies $(13,14)$. In contrast to TNF- $\alpha$, in vivo studies provide little evidence on the involvement of IL-6 in metabolic syndrome. Moreover, IL-6 is classified as both pro- and anti-inflammatory cytokine, and its concentration is the first to increase in response to exercise, followed by increased levels of well-known antiinflammatory cytokines IL-1ra and IL-10 (15).

A series of findings showed that production of TNF- $\alpha$ and other cytokines can be modified by eicosanoids. Eicosanoids, which includes prostaglandins (PG), leukotrienes (LT) and thromboxanes (TX), are signaling molecules generated from 20 carbon PUFAs, mainly arachidonic acid (AA), by the metabolic processes summarized in Figure 1. The essential proinflammatory eicosanoids $\mathrm{PGE}_{2}$ and $\mathrm{LTB}_{4}$ are derived from AA via cyclooxigenase and lipoxigenase-5 enzymatic pathways (16). However, EPA as the n-3 homologue of AA competes for the same enzymes and thus inhibit AA metabolism and suppress the generation of the n-6 inflammatory mediators (5). The relation between eicosanoids and cytokines depends on the type of mediators. Human monocytes exposed to leukotrienes (e.g. $\left.\mathrm{LTB}_{4}\right)$ release high amounts of TNF- $\alpha$ (17). On the contrary, addition of $\mathrm{PGE}_{2}$ strongly inhibited the release of TNF- $\alpha$ by macrophages (18). An enhancing role of leukotrienes on production of IL-1 and IL-6 was also advocated (19). The $n-3$ derived eicosanoids (Fig. 1) have less inflammatory or even anti-inflammatory effects; hence increasing dietary n-3 PUFAs would shift the balance of the eicosanoids formed to a less potent mixture in causing biological response. For instance, fish oil supplementation of the human diet leads to increased production of $\mathrm{LTB}_{5}, \mathrm{LTE}_{5}$, $\mathrm{PGE}_{3}$ and 5-hydroxyeicosapentaenoic acid by inflammatory cells (20). The functional significance of this is that $\mathrm{LTB}_{5}$ formed from EPA is 10-100-fold less potent as a neutrophil chemotactic agent than $\mathrm{LTB}_{4}$ derived from AA (21), while $\mathrm{PGE}_{3}$ is a less potent inducer of cyclooxygenase-2 gene expression in fibroblasts, and of IL- 6 production by macrophages than $\mathrm{PGE}_{2}$ (22). The third 20-carbon PUFA dihomo- $\gamma$-linolenic acid (DGLA) belongs to the $n-6$ family, but inspite of this, DGLA derived eicosanoids (such as PG 


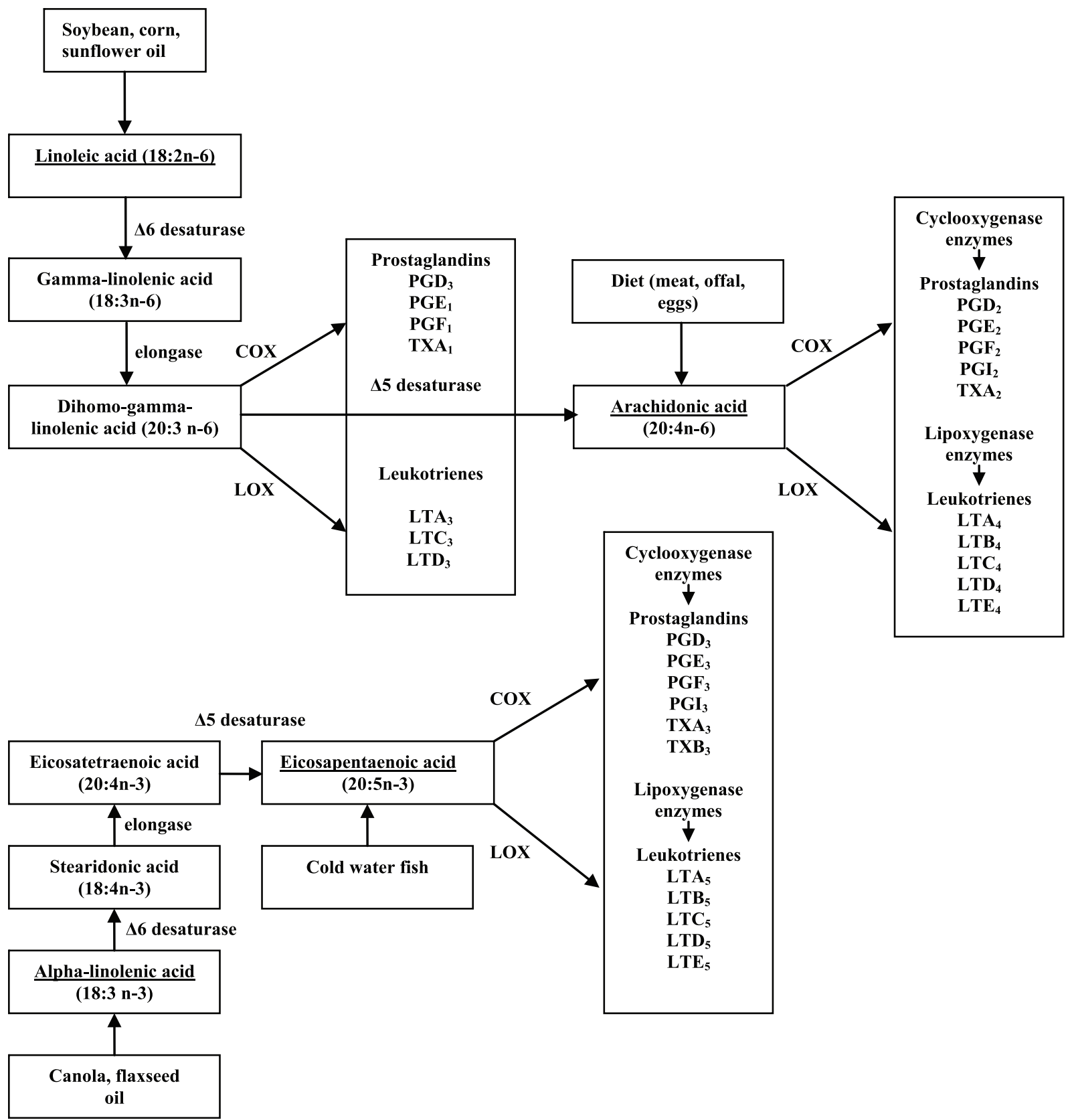

Figure 1. Dietary sources and simplified metabolism of n-3 and n-6 PUFAs

COX- cyclooxygenase, LOX-lipoxygenase (Source: Vučić V, Ristić-Medić D. Eicosapentaenoic Acid: The Role in Malignant Diseases. In Eicosapentaenoic Acid: Sources, Health Effects and Role in Disease Prevention. Editors: Theodore G. Bradley and Francisco P. Vargas. ISBN: 978-1-62257-480-3 Nova Science Publishers, Inc. pp 99-116, 2012. with written permission from the publisher).

series 1) have lower biological activity that its AA derived homologues. Similar to EPA, DGLA may reduce the production and efficacy of AA derivatives.

Besides direct effect on eicosanoids synthesis, EPA reduces the production of pro-inflammatory cytokines IL-1 and IL- 6 , as well as TNF- $\alpha$ and $-\beta$ in response to an inflammatory stimulus (23). In a community-based sample Ferrucci et al. have found (24) that total n-3 PUFAs in plasma were independently associated with lower levels of proinflammatory markers (IL-6, IL-1ra, TNF- $\alpha$, CRP) and higher levels of anti-inflammatory markers (soluble
IL-6r, IL-10, TGF- $\beta$ ) independently on confounders. The mechanisms responsible for the modulation of cytokine production by EPA and/or DHA remain unclear, although this mechanism could include suppression of eicosanoid production by n-3 PUFAs, based on the link between eicosanoids and cytokines.

Low-grade chronic inflammation is characterized by the same inflammatory mediators as an acute infection; however their levels are lower and the biologic response to a given cytokine may differ between acute and chronic inflammatory states. Multiple mechanisms may account for 
this variability, including differences in plasma cytokine/ eicosanoid concentration, presence and concentration of soluble cytokine receptors and receptor antagonists, balance of pro- versus anti-inflammatory cytokine networks, and presence of bacterial cell wall products (25).

\section{PUFAs STATUS IN SERBIAN POPULATION}

Since AA and EPA are crucial precursors for biosynthesis of eicosanoids, they have important roles in inflammation. Arachidonic acid is the most important fatty acid in production of inflammatory mediators. Although it can be ingested from meat, eggs or dairy products, AA is mostly produced from its precursor LA. Namely, comparison of fatty acid composition in vegetarians and omnivorous humans showed relatively small differences in AA level in plasma phospholipids ( $12.8 \%$ vs. $11.1 \%$ ) and cholesteryl esters $(7.8 \%$ vs. $6.5 \%)$, indicating that animal products in the diet increase the percentage of AA moderately (26).

In addition to reduced dietary intake of n- 6 PUFAs, AA level in circulation can be decreased by an increased intake of EPA. The richest food sources of EPA are oily fish (tuna, salmon, mackerel, herring, and sardine) and fish oil (27). One fish oil capsule (1g) provides about $180 \mathrm{mg}$ EPA+ $120 \mathrm{mg}$ DHA, while one oily fish meal can provide between 1.5 and 3.5 g EPA+DHA (27). Another way to obtain n-3 PUFA is metabolism of ALA to its longer chain and more unsaturated forms, including EPA, docosapentaenoic acid (DPAn-3, 22:5n-3) and DHA. However, the efficacy of this conversion is not very high and depends on the intake of LA, since both ALA and LA compete for the same elongase/desaturase enzymes. Even though ALA is the preferred substrate, it is the most rapidly oxidized among all dietary PUFAs studied in humans; therefore conversion of dietary ALA to EPA is limited. Accordingly, Brenna et al. reported that supplementation of the diet with high amounts of ALA led to small but significant increases in EPA and DPA, that was ascribed to increased oxidation of ALA, while supplementation with preformed EPA was approximately 15 -fold more efficacious in this regard (28).

In countries with low dietary intake of oily fish, levels of n-3 PUFAs in plasma phospholipids are generally low. Together with high dietary intake of LA from sunflower oil in our population, the $n-6 / n-3$ ratio became unfavorable. Proportions of plasma n-3 and n-6 PUFAs in apparently healthy Serbian population with regard to their gender and age, are summarized in Table 1.

As it can be seen from Table 1, there are small differences in plasma phospholipids PUFAs among healthy Serbian people. Proportions of LA, AA and n-6 PUFAs are high, and levels of all n-3 PUFAs are very low; thus the n-6/n-3 ratio is very high as well. A particularly high $n-6 / n-3$ ratio was found in young males (29), while the lowest ratio was reported in middle-age population (32). In comparison, proportion of LA and AA in apparently healthy population from UK and Canada showed similar results as the studies from our country, but percentage of EPA ranged 1.2-1.5\% of total fatty acids $(33,34)$, unlike $0.3-0.4 \%$ in Serbia. Thus the $n-6 / n-3$ ratio in these studies ranged 4.95-5.50, while in our country it exceeded 10.

\section{ROLE AND STATUS OF PUFAs IN LOW-GRADE INFLAMMATION}

A number of studies have investigated possible mechanisms in PUFAs modulation of the inflammatory response, but the data are often inconsistent. Beneficial anti-inflammatory effects of fish oil supplementation have been found in patients with active inflammation diseases such as rheumatoid arthritis and Crohn's disease (4), but also in patients with cancers (35) or cardiovascular disease (36). Since IL-1 and TNF are principal mediators of inflammation, reduced

\begin{tabular}{llllll}
\hline Gender/age $(\mathrm{y})$ & $\begin{array}{l}\mathrm{M} / 24.4 \pm 3.4 \\
(\mathrm{n}=19)(29)\end{array}$ & $\begin{array}{l}\mathrm{MF} / 57(19-74) \\
(\mathrm{n}=29)(30)\end{array}$ & $\begin{array}{l}\mathrm{MF} / 60(54-68) \\
(\mathrm{n}=15)(23)\end{array}$ & $\begin{array}{l}\mathrm{F} / 23.67 \pm 1.56 \\
(\mathrm{n}=14)(31)\end{array}$ & $\begin{array}{l}\text { MF/55 (44-62) } \\
(\mathrm{n}=29)(32)\end{array}$ \\
\hline LA & $26.72 \pm 2.54$ & $25.9 \pm 3.5$ & $28.39 \pm 2.81$ & $27.89 \pm 2.48$ & $26.47 \pm 2.78$ \\
DGLA & $2.96 \pm 0.72$ & $2.7 \pm 1.0$ & $2.71 \pm 0.84$ & $2.66 \pm 0.68$ & $2.42 \pm 0.71$ \\
AA & $12.74 \pm 2.14$ & $11.2 \pm 2.0$ & $12.41 \pm 2.20$ & $10.96 \pm 1.60$ & $11.56 \pm 2.32$ \\
DTA & $0.66 \pm 0.21$ & $0.3 \pm 0.2$ & $0.86 \pm 0.38$ & $0.56 \pm 0.15$ & $0.39 \pm 0.19$ \\
n-6 & $43.08 \pm 3.04$ & $40.4 \pm 3.9$ & $44.27 \pm 1.80$ & $41.51 \pm 2.47$ & $40.84 \pm 2.86$ \\
ALA & n.a. & n.a. & n.a. & $0.11 \pm 0.10$ & n.a. \\
EPA & $0.35 \pm 0.22$ & $0.3 \pm 0.2$ & $0.41 \pm 0.24$ & $0.28 \pm 0.21$ & $0.36 \pm 0.14$ \\
DPA & $0.72 \pm 0.14$ & $0.6 \pm 0.1$ & $0.71 \pm 0.16$ & $0.59 \pm 0.19$ & $0.57 \pm 0.10$ \\
DHA & $3.11 \pm 1.01$ & $3.6 \pm 1.1$ & $3.84 \pm 1.06$ & $3.26 \pm 1.33$ & $3.63 \pm 1.12$ \\
n-3 & $4.18 \pm 1.18$ & $4.5 \pm 1.3$ & $4.96 \pm 1.28$ & $4.58 \pm 1.88$ & $4.56 \pm 1.35$ \\
n-6/n-3 & $11.15 \pm 3.36$ & $9.6 \pm 2.3$ & $9.47 \pm 2.39$ & $10.76 \pm 4.89$ & $8.82 \pm 1.58$ \\
\hline
\end{tabular}

Table 1. Plasma phospholipids fatty acid composition ( $\mathrm{mol} \%$ ) with reference to apparently healthy male (M) and female (F) Serbian population 


\begin{tabular}{llllll}
\hline Sport & Basketball $(44)$ & Football $(44)$ & Boxing $(29)$ & Water polo $(31)$ & $\begin{array}{l}\text { Football }(31) \\
\text { F }(\mathrm{n}=19)\end{array}$ \\
Gender & $\mathrm{M}(\mathrm{n}=23)$ & $\mathrm{M}(\mathrm{n}=24)$ & $\mathrm{M}(\mathrm{n}=16)$ & $\mathrm{F}(\mathrm{n}=15)$ & $21.2 \pm 2.5$ \\
\hline Age $(\mathrm{y})$ & $21 \pm 4$ & $24 \pm 5$ & $22.4 \pm 3.3$ & $21.7 \pm 4.5$ & $25.06 \pm 2.04$ \\
\hline LA & $25.67 \pm 2.50$ & $26.00 \pm 2.85$ & $23.03 \pm 2.63$ & $25.60 \pm 3.02$ & $2.46 \pm 0.65$ \\
DGLA & $3.32 \pm 0.85$ & $3.24 \pm 0.67$ & $2.26 \pm 0.48$ & $2.76 \pm 0.78$ & $11.50 \pm 1.25$ \\
AA & $13.98 \pm 1.92$ & $12.64 \pm 1.66$ & $9.29 \pm 1.72$ & $12.44 \pm 1.89$ & $0.61 \pm 0.24$ \\
DTA & $0.93 \pm 0.28$ & $0.61 \pm 0.13$ & $0.64 \pm 0.33$ & $0.71 \pm 0.25$ & $39.63 \pm 1.90$ \\
n-6 & $43.90 \pm 2.16$ & $42.49 \pm 2.33$ & $35.20 \pm 3.47$ & $41.51 \pm 2.47$ & $0.14 \pm 0.10$ \\
ALA & $n . a$. & $n . a$. & $n . a$. & $0.15 \pm 0.12$ & $0.30 \pm 0.20$ \\
EPA & $0.47 \pm 0.20$ & $0.39 \pm 0.11$ & $0.29 \pm 0.19$ & $0.36 \pm 0.26$ & $0.66 \pm 0.19$ \\
DPA & $0.79 \pm 0.18$ & $0.73 \pm 0.14$ & $0.47 \pm 0.23$ & $0.77 \pm 0.30$ & $2.68 \pm 0.73$ \\
DHA & $3.05 \pm 0.85$ & $3.10 \pm 0.73$ & $1.60 \pm 0.85$ & $3.30 \pm 1.34$ & $3.78 \pm 0.98$ \\
n-3 & $4.31 \pm 0.99$ & $4.22 \pm 0.81$ & $2.36 \pm 1.07$ & $4.58 \pm 1.88$ & $11.13 \pm 2.78$ \\
n-6/n-3 & $10.66 \pm 2.26$ & $10.17 \pm 1.98$ & $17.77 \pm 8.04$ & $10.76 \pm 4.89$ & \\
\hline
\end{tabular}

Table 2. Plasma phospholipids fatty acid composition (mol \%) in elite male (M) and female (F) Serbian athletes

production of these cytokines may contribute to the amelioration of inflammatory symptoms in patients taking n-3 supplementation. Dietary supplementation with n-3 PUFAs in healthy subjects resulted in reduced levels of proinflammatory cytokines (IL-1, IL-2, PGE 2 and thromboxane 2) and decreased mononuclear cell proliferation (37). Preclinical studies indicated that decreased generation of proinflammatory cytokines is a consequence of altered gene expression, including transcriptional down-regulation and suppressed cyclooxygenase-2 activity (4). One of the possible mechanisms of $n-3$ PUFAs impact on inflammatory gene expression is modification of the activities of transcription factors. Two transcription factors that are likely involved in inflammation are nuclear factor $\kappa \mathrm{B}(\mathrm{NF} \kappa \mathrm{B})$ and peroxisome proliferator activated receptor (PPAR). There are 4 isoforms of PPAR: $\alpha, \beta, \delta$ and $\gamma$, and EPA has been found to bind and activate at least PPAR- $\alpha$ and $-\gamma$ isoforms. The PPAR- $\alpha$ is expressed in many types of human cells, including atherosclerotic plaques macrophages, while PPAR- $\gamma$ is expressed in the immune cells (lymphocytes, monocytes, and macrophages), dendritic and many other cells (38). $\mathrm{NF} k \mathrm{~B}$ has been shown to up-regulate inflammatory cytokines (TNF- $\alpha$, IL- 6, IL-1), adhesion molecules and COX-2 genes. On the contrary, PPAR reduces inflammatory gene expression, and also interferes with the activation of $\mathrm{NF} \mathrm{B}$ (39). Namely, the NFKB is activated by protein kinase C catalized phosphorylation, and subsequent dissociation of its inhibitory subunit. However, n-3 PUFAs have been shown to directly inhibit protein kinase $C$, and thereby decrease NFkB activation (38). Furthermore, NFkB can be inhibited by directly binding to PPAR- $\gamma$, which is activated by $n-3$ PUFAs. In vitro studies have also documented decreased activation of $\mathrm{NF}_{\mathrm{K}} \mathrm{B}$ in response to different inflammatory stimuli after treatment with EPA (40). These data are clinically significant, because reduced NFKB and consequently reduced IL-1 and IL- 6 in circulation will result in decreased production of CRP, which is related to the cardiovascular disease events and their severity (41).

PUFAs status is therefore essential in development of chronic non-communicable diseases. In addition to dietary intake, PUFAs status depends on metabolic processes in the body, which are often altered in inflammation. The results in Serbian patients with chronic diseases showed that levels of n-3 and n-6 PUFAs in plasma phospholipids, as well as their ratio were usually altered: the $n-6 / n-3$ ratio ranged from 11.2 in diabetic patients (42) to 15.4 in patients with non-Hodgkin's lymphoma (NHL) (30). Moreover, we have recently found that the $n-6 / n-3$ ratio in NHL patients varied in response to chemotherapy from 8.5 in patients in remission, to even 19.3 in patients with progression of NHL (43). These results are in accordance with a study by Xia et al. who showed that elevated n-6/n-3 PUFAs ratio stimulated carcinogenesis, tumor growth and metastasis (44).

Besides chronic non-communicable diseases, low grade systemic inflammation is found in elite athletes engaged in prolonged, intensive trainings. Although regular moderate exercise has beneficial impact on health, chronic severe physical activity induces increased levels of cytokine and eicosanoids in circulation. For this reason, altered PUFA profiles are expected in elite athletes, as presented in Table 2. The n-6/n-3 ratio in all tested Serbian athletes is relatively high, especially in boxers. Interestingly, these sportsmen do not have high levels of n-6 PUFAs (which are even lower than in the other athletes), but very low proportion of $n-3$ PUFAs. Athletes engaged in heavy training programs appear to be more susceptible to infections than sedentary population due to a depression of immune system function, which could be explained by unfavorable PUFAs ratios (45). Based on these results, nutritional intervention and $\mathrm{n}-3$ supplementation in all sport groups is recommended, and in boxers both n-6 and n-3 PUFAs intake should be markedly increased. 


\section{DIETARY RECOMMENDATION}

In spite of convincing evidence of a relationship between PUFAs intake and development of chronic diseases, only a sparse amount of human data is available for establishing a precise quantitative estimate of the n-3 and n-6 PUFAs requirement to prevent deficiency and provide optimal intake. According to the FAO/WHO report from 2008, the adequate intake to prevent deficiency is $2.5-3.5 \%$ of total energy intake (\%E), while the minimum intake levels for EFA should be $2.5 \%$ LA plus $0.5 \%$ ALA (46). However, an effective intake for the prevention of chronic diseases is considered to be 6-11\% $\mathrm{E}$ (47). In addition, 0.250-2.0g of EPA+DHA daily should be included in the diet (46). In order to improve the $n-6 / n-3$ ratio, it will be necessary to decrease the intake of n-6 PUFAs from vegetable oils and to increase the intake of n-3 PUFAs by using oils rich in ALA, increase the intake of oily fish to 2-3 times per week or take $\mathrm{n}-3$ supplements.

\section{CONCLUDING REMARIS}

Unhealthy diet with an imbalanced proportion of daily intake of n-3 and n-6 PUFAs is the main cause of low-grade systemic inflammation, which leads to the development of chronic diseases. The balanced intake of all fatty acids, particularly with regard to $n-6 / n-3$ ratio, may help to prevent and reduce the chronic inflammation and diseases.

\section{ACKNOWLEGMENTS}

This study was supported by the Grant No. III 41030 from the Ministry of Education, Science and Technological Development of the Republic of Serbia.

\section{REFERENCES:}

1. Petersen AM, Pedersen BK. The anti-inflammatory effect of exercise. J Appl Physiol 2005; 98(4): 1154-62.

2. Mathur N, Pedersen BK. Exercise as a mean to control low-grade systemic inflammation. Mediators Inflamm 2008; 2008: 109502.

3. WHO. Techical Report Series 916. Diet, nutrition and the prevention of chronic diseases. Geneva, Switzerland, 2003. http://whqlibdoc.who.int/trs/who_trs_916.pdf

4. Calder PC. Polyunsaturated fatty acids, inflammatory processes and inflammatory bowel diseases. Mol Nutr Food Res 2008; 52(8): 885-97.

5. James MJ, Gibson RA, Cleland LG. Dietary polyunsaturated fatty acids and inflammatory mediator production. Am J Clin Nutr 2000; 71(1 Suppl): 343S-8S.

6. Burdge GC, Calder PC. Dietary alpha-linolenic acid and health-related outcomes: a metabolic perspective. Nutr Res Rev 2006;19(1):26-52.
7. Vucic V, Tepsic J, Arsic A, Popovic T, Debeljak-Martacic J, Glibetic M. Fatty acid content of vegetable oils and assessment of their consumption in Serbia. Acta Alimentaria 2012; 41(3) :343-50.

8. Bruunsgaard H. Physical activity and modulation of systemic low-level inflammation. J Leukoc Biol 2005;78(4):819-35.

9. Bennet AM, Prince JA, Fei GZ, Lyrenas L, Huang Y, Wiman B, et al. Interleukin-6 serum levels and genotypes influence the risk for myocardial infarction. Atherosclerosis. 2003 Dec;171(2):359-67.

10. Cook NR, Buring JE, Ridker PM. The effect of including C-reactive protein in cardiovascular risk prediction models for women. Ann Intern Med 2006;145(1) :21-9.

11. Reilly MP, Rohatgi A, McMahon K, Wolfe ML, Pinto SC, Rhodes T, et al. Plasma cytokines, metabolic syndrome, and atherosclerosis in humans. J Investig Med 2007; 55(1): 26-35.

12. Zeyda M, Farmer D, Todoric J, Aszmann O, Speiser M, Gyori G, et al. Human adipose tissue macrophages are of an anti-inflammatory phenotype but capable of excessive pro-inflammatory mediator production. Int J Obes (Lond) 2007; 31(9) :1420-8.

13. Plomgaard P, Nielsen AR, Fischer CP, Mortensen $\mathrm{OH}$, Broholm C, Penkowa M, et al. Associations between insulin resistance and TNF-alpha in plasma, skeletal muscle and adipose tissue in humans with and without type 2 diabetes. Diabetologia 2007; 50(12): 2562-71.

14. Ruan H, Lodish HF. Insulin resistance in adipose tissue: direct and indirect effects of tumor necrosis factor-alpha. Cytokine Growth Factor Rev 2003;14(5): 447-55.

15. Pedersen BK, Fischer CP. Physiological roles of muscle-derived interleukin- 6 in response to exercise. Curr Opin Clin Nutr Metab Care 2007;10(3): 265-71.

16. Ristic-Medic D, Suzic S, Vucic V, Takic M, Tepsic J, Glibetic M. Serum and erythrocyte membrane phospholipids fatty acid composition in hyperlipidemia: effects of dietary intervention and combined diet and fibrate therapy. Gen Physiol Biophys 2009; 28 Spec No: 190-9.

17. Gagnon L, Filion LG, Dubois C, Rola-Pleszczynski M. Leukotrienes and macrophage activation: augmented cytotoxic activity and enhanced interleukin 1, tumor necrosis factor and hydrogen peroxide production. Agents Actions 1989; 26(1-2): 141-7.

18. Kunkel SL, Spengler M, May MA, Spengler R, Larrick J, Remick D. Prostaglandin E2 regulates macrophagederived tumor necrosis factor gene expression. J Biol Chem 1988; 263(11): 5380-4.

19. Weaver KL, Ivester P, Seeds M, Case LD, Arm JP, Chilton FH. Effect of dietary fatty acids on inflammatory gene expression in healthy humans. J Biol Chem 2009; 284(23): 15400-7.

20. Sperling RI, Benincaso AI, Knoell CT, Larkin JK, Austen KF, Robinson DR. Dietary omega-3 polyunsaturated fatty acids inhibit phosphoinositide formation and chemotaxis in neutrophils. J Clin Invest 1993; 91(2): 651-60. 
21. Lee TH, Menica-Huerta JM, Shih C, Corey EJ, Lewis RA, Austen KF. Characterization and biologic properties of 5,12-dihydroxy derivatives of eicosapentaenoic acid, including leukotriene B5 and the double lipoxygenase product. J Biol Chem 1984; 259(4): 2383-9.

22. Bagga D, Wang L, Farias-Eisner R, Glaspy JA, Reddy ST. Differential effects of prostaglandin derived from omega- 6 and omega- 3 polyunsaturated fatty acids on COX-2 expression and IL-6 secretion. Proc Natl Acad Sci U S A 2003;100(4): 1751-6.

23. Popovic T, Ranic M, Bulajic P, Milicevic M, Arsic A, Vucic V, et al. Effects of n-3 Fatty Acids Supplementation on Plasma Phospholipids Fatty Acid Composition in Patients with Obstructive Jaundice- a Pilot Study. J Clin Biochem Nutr 2009;45(3): 370-5.

24. Ferrucci L, Cherubini A, Bandinelli S, Bartali B, Corsi A, Lauretani F, et al. Relationship of plasma polyunsaturated fatty acids to circulating inflammatory markers. J Clin Endocrinol Metab 2006;91(2) :439-46.

25 . Wisse BE. The inflammatory syndrome: the role of adipose tissue cytokines in metabolic disorders linked to obesity. J Am Soc Nephrol 2004;15(11): 2792-800.

26. Phinney SD, Odin RS, Johnson SB, Holman RT. Reduced arachidonate in serum phospholipids and cholesteryl esters associated with vegetarian diets in humans. Am J Clin Nutr 1990;51(3): 385-92.

27. Ristić-Medić D, Vučić V, Takić M, Karadžić I, Glibetić M. Polyunsaturated fatty acids in health and disease. J Serb Chem Soc 2013;78: 1-21.

28. Brenna JT, Salem N, Jr., Sinclair AJ, Cunnane SC. alphaLinolenic acid supplementation and conversion to n-3 long-chain polyunsaturated fatty acids in humans. Prostaglandins Leukot Essent Fatty Acids 2009; 80(2-3): 85-91.

29. Tepsic J, Vucic V, Arsic A, Mazic S, Djelic M, Glibetic M. Unfavourable plasma and erythrocyte phospholipid fatty acid profile in elite amateur boxers. Eur J Sport Sci 2013; 13(4): 414-21.

30. Cvetkovic Z, Vucic V, Cvetkovic B, Petrovic M, RisticMedic D, Tepsic J, et al. Abnormal fatty acid distribution of the serum phospholipids of patients with non-Hodgkin lymphoma. Ann Hematol 2010; 89(8): 775-82.

31. Arsic A, Vucic V, Tepsic J, Mazic S, Djelic M, Glibetic M. Altered plasma and erythrocyte phospholipid fatty acid profile in elite female water polo and football players. Appl Physiol Nutr Metab 2012; 37(1): 40-7.

32. Ristic V, Tepsic V, Ristic-Medie D, Perunicic G, Rasic Z, Postic M, et al. Plasma and erythrocyte phospholipid fatty acids composition in Serbian hemodialyzed patients. Ren Fail 2006; 28(3): 211-6.

33. Lisboa AQ, Rezende M, Muniz-Junqueira MI, Ito MK. Altered plasma phospholipid fatty acids and nutritional status in patients with uterine cervical cancer. Clin Nutr 2008; 27(3): 371-7.

34. McClinton S, Moffat LE, Horrobin DF, Manku MS. Abnormalities of essential fatty acid distribution in the plasma phospholipids of patients with bladder cancer. Br J Cancer 1991; 63(2): 314-6.
35. Murphy RA, Mourtzakis M, Chu QS, Baracos VE, Reiman T, Mazurak VC. Supplementation with fish oil increases first-line chemotherapy efficacy in patients with advanced nonsmall cell lung cancer. Cancer 2011; 117(16): 3774-80.

36. Wang C, Harris WS, Chung M, Lichtenstein AH, Balk EM, Kupelnick B, et al. n-3 Fatty acids from fish or fishoil supplements, but not alpha-linolenic acid, benefit cardiovascular disease outcomes in primary- and secondary-prevention studies: a systematic review. Am J Clin Nutr 2006; 84(1): 5-17.

37. Endres S, Meydani SN, Ghorbani R, Schindler R, Dinarello CA. Dietary supplementation with $n-3$ fatty acids suppresses interleukin-2 production and mononuclear cell proliferation. J Leukoc Biol 1993;54(6): 599-603.

38. Wardhana, Surachmanto ES, Datau EA. The role of omega-3 fatty acids contained in olive oil on chronic inflammation. Acta Med Indones 2011; 43(2): 138-43.

39. Vanden Berghe W, Vermeulen L, Delerive P, De Bosscher K, Staels B, Haegeman G. A paradigm for gene regulation: inflammation, NF-kappaB and PPAR. Adv Exp Med Biol 2003; 544: 181-96.

40. Kliewer SA, Sundseth SS, Jones SA, Brown PJ, Wisely GB, Koble CS, et al. Fatty acids and eicosanoids regulate gene expression through direct interactions with peroxisome proliferator-activated receptors alpha and gamma. Proc Natl Acad Sci U S A 1997; 94(9): 4318-23.

41. Devaraj S, Valleggi S, Siegel D, Jialal I. Role of C-reactive protein in contributing to increased cardiovascular risk in metabolic syndrome. Curr Atheroscler Rep 2010; 12(2): 110-8.

42. Ristic Medic D, Ristic V, Arsic A, Postic M, Ristic G, Blazencic Mladenovic V, et al. Effects of soybean DLeciVita product on serum lipids and fatty acid composition in type 2 diabetic patients with hyperlipidemia. Nutr Metab Cardiovasc Dis 2006; 16(6): 395-404.

43. Cvetković Z, Vučić V, Cvetković B, Karadžić I, Ranić M, Glibetić M. Distribution of plasma fatty acids is associated with response to chemotherapy in non-Hodgkin's lymphoma patients. Med Oncol. 2013;30(4): 741-6.

44. Xia SH, Wang J, Kang JX. Decreased n-6/n-3 fatty acid ratio reduces the invasive potential of human lung cancer cells by downregulation of cell adhesion/invasionrelated genes. Carcinogenesis 2005; 26(4): 779-84.

45. Tepsic J, Vucic V, Arsic A, Blazencic-Mladenovic V, Mazic S, Glibetic M. Plasma and erythrocyte phospholipid fatty acid profile in professional basketball and football players. Eur J Appl Physiol 2009;107(3): 359-65.

46. Joint FAO and WHO Expert Consultation. Fats and fatty acids in human nutrition. Geneva 2008. http://www. fao.org/docrep/013/i1953e/i1953e00.pdf

47. Simopoulos AP. The importance of the omega-6/ omega-3 fatty acid ratio in cardiovascular disease and other chronic diseases. Exp Biol Med (Maywood) 2008; 233(6): 674-88. 